\title{
Martyn Housden
}

\section{Intellectual Resistance:}

\section{Paul Schiemann's Rejection of "the New Nationalist Wave"}

Paul Schiemann's name is well-known only in relatively small academic circles, for example among historians interested in Latvia, the Baltic states and German national minorities. He had formidable intellectual strength, clear moral vision and substantial personal courage, all of which enabled him to resist the rise of Nazism among German national minorities. This paper explains Schiemann's world view, together with his attempts to promote values of tolerance and justice in the face of destructive nationalism.

\section{Introduction}

"Thinking people" should always lead the fight against intolerance and injustice, shouldn't they? Certainly some well-known cases of intellectual resistance to Nazism occurred during the war years when, for instance, the Kreisau Circle met to discuss how to build a post-war state based on local democracy, the White Rose group wrote pamphlets charged with moral outrage and, from abroad, Thomas Mann broadcast his critique of National Socialism. ${ }^{1}$ By contrast, before 1939 Germany's cultured social circles were often disappointingly accepting of National Socialist values. In spring 1933, unperturbed by association with the new government, philosopher Martin Heidegger became Rector of the University of Freiburg; in May, the renowned legal theorist Carl Schmitt joined the Nazi Party. ${ }^{2}$ Sadly, these high-profile cases of moral torpor were not atypical. Too quickly, too many well-educated professionals precipitated to Hitler's movement such that, for example, by October 1933 the Association of National Socialist German Jurists had 30,000 members. ${ }^{3}$ Hence psychiatrist at the Nuremberg trials G.M. Gilbert wrote about the "well-educated intellectuals who might have been presumed to 


\section{Housden}

have more rational frames of reference to evaluate the appeals of dictatorial demagoguery", but who at speed chose to follow Hitler anyway. ${ }^{4}$

Nonetheless, intellectual resistance to Nazism was not limited to the war years. In fact, even before Hitler became Chancellor of Germany at least some clear-thinking German intellectuals spoke out unambiguously, and at personal cost, against his politics. This paper examines one such case. As it does so, it takes the word "intellectual" to denote a well-educated person for whom engagement with ideas is an important part of life; likewise, "resistance" designates a stand taken against a political movement, as a matter of principle and practice, which is likely to put the welfare and interests of an individual at risk.

\section{Democratic politics and vulnerable groups in Latvia}

Paul Schiemann (1876-1944) was not a citizen of Germany; he was an "ethnic German" who came to participate in the German national minorities' movement, as well as the movement of Europe's national minorities, until a fundamental breach came for him in summer 1932. He was a Baltic German, born in 1876 in Mitau in the Baltic Provinces of the Russian Empire (today Jelgava, Latvia). He received an extensive education at several German universities before obtaining a doctorate from Greifswald in $1902 .{ }^{5}$ Thereafter he returned to the Baltic region where he became, first, a journalist for Revalsche Zeitung (based in Reval, today Tallinn, Estonia) and, subsequently political editor for Rigasche Rundschau (based in Riga, today the capital of Latvia). ${ }^{6}$

Schiemann's career in the media was broken by the First World War, during which he served in the Russian Army. At the end of war, he returned to Riga where he became committed to the causes of democracy and the construction of new, independent Baltic states. In 1919 he took over as editor-in-chief of Rigasche Rundschau, a post which he held until 1933, during which time he turned it into probably the most important Germanlanguage newspaper in Eastern Europe. Until 1925, he was a member of the Riga city council, but more importantly he was a long-term member of the Latvian parliament, where he represented the Baltic German community. At an early point in his career as a parliamentary politician, he spoke up for the rights of Latvia's national minorities, a cause which he publicised widely through his ongoing journalism for Rigasche Rundschau. As he once 
commented, "We cannot tolerate the violent de-nationing of the children of our economically weak national comrades...." For Baltic Germans every single member of their community was important because, according to figures from 1920, they numbered less than $4 \%$ of Latvia's population. ${ }^{8}$ This numerical weakness meant it would be all too easy for their interests to become lost in a system of political decision making based on majority voting. Schiemann understood that, in a modern democracy, some groups needed special consideration. As a result, he promoted the rights of Latvia's national minorities to have autonomous schooling, a measure achieved in December 1920.

Even in the early 1920s, the force of Schiemann's rhetoric was palpable. He emphasised that, in demanding minority rights, Latvia's ethnic Germans were not in search of charity or special favours; they were only demanding their due as historical residents of Latvian territory and the recognition of those values which should be integral to any civilized state:

We are not just tolerated foreigners in the land who are requesting protection, but long-established state citizens who have to turn into reality those rights which can exhibit the intellectual values which a yet-to-be-built state cannot do without. ${ }^{9}$

With remarkable prescience, at this early stage Schiemann recognised how popularist politics, designed to mobilise the emotions of the masses, could present a particular danger in a Europe still febrile in the aftermath of war. Speaking of worrying tendencies which he discerned in Latvia's social democratic party, Schiemann commented:

You will agree with me that the long war, with its violent enflaming of all Mankind's passions and animal instincts, has precipitated a serious disease of national spirits in all the countries of Europe. No matter whether this sickness is expressed, here, in Bolshevist outrages or, there, in chauvinistic ones, the germ of the illness is the same. If at such a time the party which has the closest relationship to the broad masses of the people gives up the ambition to participate in healing this psychological disease and turns itself into the tool of the passions, then the state is brought to the verge of collapse. ${ }^{10}$

Writing in a Latvian context, and at a time before Nazism had become a significant force in Germany, Schiemann warned of the threat that rabblerousing politics could pose to national minorities: 


\section{Housden}

The more an institution is dependent on the favour of the masses, the more it is necessary for it to characterise the national minorities, especially the Balts [i.e. the Baltic Germans], as enemies. ${ }^{11}$

To Schiemann's mind, democratic politics had to involve more than building popular support on emotion and the scapegoating of easy targets. It had to involve ethical leadership:

The democrat does not only have the duty to protect the interests of the broad masses of the nation, but also to protect the individual against victimisation. Even the most minor thing that a democratic leader does in contradiction to better knowledge damages the polity as a whole. ${ }^{12}$

For Schiemann, democracy had to serve not only the interests of people who voted for a majority political party, but (in some important respects at least) the interests of everyone living on the state's territory.

Schiemann's mission for ethnically inclusive politics was not intended to benefit the Baltic Germans alone. He was explicit that all national (or ethnic) minority groups in Latvia should be treated decently. He advocated that not only Germans, but also "Russian and Jewish Latvian state citizens" should not be made to "feel like foreigners in the state, but rather fully-recognised citizens rooted in the homeland (Heimat)."13 Hence, when Latvia's Jews were banned from opening shops on Sunday, Schiemann spoke in their favour. ${ }^{14}$ A little later, he wrote a series of articles in which he denounced political anti-Semitism as having no achievable aims (since, he thought, in the modern world Jews could be neither "rooted out" nor forced to emigrate) and as being self-defeating (since, in the end, race-hatred's aggression damaged one's own nation and state). ${ }^{15}$

\section{The international stage}

Inside Latvia, Paul Schiemann did his best to promote an idea of inclusive democracy which incorporated the interests of national and ethnic minorities; as the 1920s progressed, increasingly he took these ideas onto the international stage. This was a period of post-war reconstruction. In Europe, old empires were being broken up and new democratic nation states were being founded. Despite the term "nation state", the new states in fact never were home to just one national group. Hence, for instance, Latvia was populated by Latvians, but also Swedes, Russians, Jews and of course Germans. Estimates suggested that 20 to 40 million people lived as national 
minorities in the new and extended states of Central and Eastern Europe. ${ }^{16}$ The question of national minorities in this region was especially sensitive because relations between majorities and minorities often were strained as a result of experiences of empire, war and occupation. Furthermore, tension involving ethnic German groups was held a risk that might draw the German state to interfere in a neighbour's domestic politics, while there was also fear that inter-ethnic tension might be exploited by Bolshevik Russia to help de-stabilise states on its borders. ${ }^{17}$ It followed that as part of the post-war settlement, first, the Allied Powers and later, the League of Nations made it their job to supervise the treatment of national minorities in the new and expanded states of Central and Eastern Europe, each of which was compelled to enter into an international agreement to facilitate this end.$^{18}$ Respect for the rights of national minorities in the region was, then, a matter of deep international interest.

German minorities, however, were uncomfortable entrusting minority protection to statesmen alone, not least because as a rule they (the statesmen) came from national majority peoples; German minorities wanted access to the international political stage themselves in order to participate in the supervision of their own rights. This engagement began seriously in 1922 when ethnic Germans established the Association of German Minorities in Europe. The organisational work was led by Ewald Ammende (from Estonia) and Rudolf Brandsch (from Romania), but Paul Schiemann was important too. It is necessary to emphasise that, when the organisation was established, its goal was not to revise the post-war peace settlement, hence it renounced campaigning to change Europe's post-war borders. Rather, it saw its purpose as to help: "...to defeat the cancer in the body of our continent, namely national hatred-which causes ninety nine percent of the cases of oppression and violence towards national minorities." ${ }^{\prime 19}$

The Association was an important initiative, but it understood itself to be only a beginning. One of its founding memoranda noted that German minorities were fighting over issues that had to be of interest to all Europe's national minorities and looked to the day when all these groups might organise as a whole. ${ }^{20}$ This day came in 1925 when, in a project driven along by Ewald Ammende especially, the European Congress of Nationalities met in Geneva (the seat of the League of Nations). Representatives of 33 organised national groups, drawn from 12 nationalities located in 14 separate states met in order to publicise general awareness of minority affairs and to lobby the League of Nations about issues close to their hearts. ${ }^{21}$ Again, like the 


\section{Housden}

Association, the Congress was never supposed to demand revision of the post-war settlement and, moreover, was supposed only to discuss matters of principle rather than concrete cases of the maltreatment of minorities. (The latter measure was an attempt to prevent emotional clashes on national lines between Congress speakers.) In the 1920s, Paul Schiemann became arguably the most intellectually formidable contributor to the Congress's proceedings.

\section{The "a-national state"}

Schiemann's speech to the Congress in 1925 was the event's intellectual high point. ${ }^{22}$ Developing more generally his thinking already established in the context of Latvian democracy, Schiemann moved through historical analogy. The Thirty Years War had led to the realisation that religious convictions were so fundamental to individuals that the state should never try to intervene between a person and his or her God. Schiemann proposed that the First World War might one day be recognised as the war which discredited interference in the relationship between the individual and his or her sense of national cultural identity.

Addressing especially the problem of assimilation, Schiemann argued perceptively that attempts to destroy the culture of minorities in fact threatened the culture of majorities too; when a state attacked the economic position of a minority, it damaged the economic success of majority people too; and when a state's legal system treated people differently according to their ethnicity, then it destroyed the foundations of justice necessary for a successful society. Worse, he said, once discrimination against any given group had become established, hatred of that group was likely only to intensify until it became "a will to annihilation". In contrast to this pessimistic possibility, Schiemann looked to the Congress to champion "united, positive work" between different national groups in order to create "peace" in Europe.

Clearly Schiemann was looking for the creation of a state and society in which people of different nationality could coexist in ways that involved the minimization of inter-ethnic friction: in effect, he was exploring an idea of how a successful multicultural society might be organised. He developed his thinking further the next year when he used another speech to the Congress in 1926 to outline his ideas not of a "nation state", but of an "a-national state".

Schiemann re-capped: he wanted a world in which national cultural affiliation was as much a matter of personal freedom as religious confession and that peace depended on the aim's achievement. ${ }^{23}$ In this light, he proposed 
that "the state" (and the territory it occupied) should no longer be linked to the idea of "the nation". This linkage (expressed so clearly in the phrase "nation state") served only the interests of majority national populations and led to the marginalisation of national minorities. When the police were only a national police force, when an economy served only one national group and when the state only respected one nationality, then unity of all under a given state structure plainly was impossible.

Thinking in ways which he recognised as almost utopian in the context of the 1920s, Schiemann advocated moving towards an "a-national concept" of the state. Again, using historical analogy, he pointed out that past dynastic states had been "a-national", with the dynastic leader representing everyone who lived on his or her territory. It was only with the rise of modern nationalist thinking that this early inclusive idea broke down. Schiemann wanted to regain the "a-national" idea in which the state should represent a "political nation" of all the citizens on its territory rather than an "ethnic nation" which excluded minorities. More radically still, but quite logically, Schiemann proposed that one day Europe might even be divided into not only a single structure of state communities, but also a parallel structure of national communities. Here, state communities would address the needs of all people living on given state territories (e.g. in terms of economics, security, law and order, and foreign policy), while national communities would nurture their national cultures separately and autonomously. (It is worth highlighting that Schiemann was also quite clear that autonomous national cultural communities had to remain completely loyal to the states in which they lived. $)^{24}$

\section{Resisting German National Socialism}

By the mid-1920s, Paul Schiemann had developed an unconventional multicultural vision for the transformation of individual states and for Europe as a whole. Given the nature of the historical period, it was only a matter of time before his ideas led him into open conflict with Germany's National Socialist movement.

Key German National Socialists hated the multiculturalism that Schiemann stood for. The Nazi ideological guru, Alfred Rosenberg (18931946; born in Tallinn) described the national minorities' movement as "racial pollution and spiritual murder elevated to a world political program." ${ }^{25}$ For his part, Adolf Hitler was prepared to sell out German national minorities if it 


\section{Housden}

suited his purpose. Hence, when Mussolini undertook measures to assimilate ethnic Germans in South Tyrol, Hitler prioritised a good relationship with the Duce over the well-being of ethnic Germans. ${ }^{26}$

Unsurprisingly, on occasion Schiemann took issue directly with German National Socialism. He even mocked it:

'Germany for the Germans!'

What well known talk for every politician in the East!

Latvia for the Latvians! Poland for the Poles! Romania for the Romanians! Greater Serbia for the Serbs! $!^{27}$

Schiemann's most famous act of intellectual resistance to National Socialism, however, came in early summer 1932 and reflected his minority-aware, inclusive view of politics. In terms of context, changes had been happening inside the German national minorities' movement since the late 1920s. There had been a rise of more nationally assertive voices and a new mood could be traced when, in 1928, the Association ditched the word "Minorities" from its title and re-named itself the Association of German National Groups in Europe. The name change was supposed to indicate that there was nothing "minor" about the group's membership. Moreover, in 1930 Weimar Germany experienced Nazism's breakthrough in that September's Reichstag elections. ${ }^{28}$ Thereafter, the closer the Nazi Party came to power in Berlin, the greater was the infection of German minorities outside the German state with its racialist message. This "infection" was manifested especially clearly in the journal Nation and State, which was run by German national minorities and which received some funding from the German Foreign Office in Berlin. ${ }^{29}$ Amongst others, Paul Schiemann was one of the journal's editors.

Notwithstanding Schiemann's involvement, in October 1932 Nation and State published an article by a Nazi Party official from Austria called Norbert Gürke. ${ }^{30}$ The article argued that race determined a nation's membership and culture, and that the involvement of non-Germans (e.g. to quote the article, "Mongols", "blacks" and "Jews") in Germany's public life was causing damage. This was something quite new to the journal's pages; and the problem didn't stop there. The fact that too many German minority activists were ready to co-operate with Nazism was again displayed clearly in mid-1933 when one of the journal's other editors, Ferdinand von Üxküll (1890-1939; born on Estonian territory) wrote that the German nation had the right to eject 
Jews from its national body (a process which was termed "dissimilation"). ${ }^{31}$

Paul Schiemann's most dramatic act of intellectual resistance took place in the midst of the creeping subversion of the German national minorities' movement by Nazi values and soon before the publication of Gürke's article. It took the form of a talk entitled "The New Nationalist Wave" which he delivered to the Association of German National Groups in Europe at a meeting near Vienna on 23 June 1932. Subsequently the talk was published in Nation and State. ${ }^{32}$ Schiemann's text provided a devastating critique of National Socialism.

They were living, he said, in a time of crisis in which spirits of war and peace were locked in battle and in which peace increasingly was seen as an opportunity to pursue war "by other means". As this happened, ever more people were fleeing into separate communities such that the "mass" increasingly was becoming a decisive factor in politics; at the same time personal moral values were being replaced by irrational urges and loyalty to partisan symbols. Politics was becoming increasingly hostile and "national community" was being conflated with "state community". Under these circumstances, whoever denounced foreigners most loudly began to appear the best patriot.

Schiemann had a reputation for being "the thinker of the minorities' movement" and, as he argued, he turned telling phrase after telling phrase; for example: "Service to the nation cannot be placed above moral law, if we do not want to destroy completely the meaning of moral law." ${ }^{33}$ He denounced "a new nationalist wave" washing over multi-ethnic Eastern Europe which led to the reification of the nation state above all else. He spoke out against "sermons" coming from the West (i.e. from Germany) which were damaging the region's young people and subverting the fight for minority rights. After all, how could German minorities in Eastern Europe demand minority rights for themselves when co-nationals in the German state were committed to the denial of rights to minorities there?

How are we supposed to carry forward our struggle for justice and fight for full equality? (...) How are we supposed to battle for justice and freedom when day after day it is held against us that precisely such rights are fundamentally contested by a steadily growing number of our own people ? $^{34}$

Schiemann drew to a close: 


\section{Housden}

We must not only lead a [sense of justice] against the nationalism found in foreign camps among our majority peoples [i.e. in East European states], rather we must determinedly and righteously lead it against the nationalism in our own camp, even against the nationalism of our own national comrades. ${ }^{35}$

The speech signalled that Schiemann's ties with the Association of German National Groups in Europe could not last for much longer. Since funding from the German state helped support not just the Association, but the European Congress of Nationalities too, in time his role there became curtailed as well. Once Hitler was in power in Berlin, Schiemann lost his positions in Nation and State and Rigasche Rundschau (which also received financial support from the German Foreign Office in Berlin). From January 1933 on, the subversion of the German and European national minorities' movements by Nazism intensified, but that is a separate story. ${ }^{36}$

\section{Conclusion: who is remembered in History?}

Paul Schiemann was not perfect. It should be admitted that he did rather take it for granted that German culture held pride of place among European cultures.$^{37}$ However, given the time and place in which he lived, Schiemann's failings were small compared to those of many other intellectuals. Referring to Martin Heidegger again, although he stepped down as Rector of Freiburg University in early 1934, his private notebooks show a kind of susceptibility to anti-Semitism which had absolutely no parallel in Schiemann. ${ }^{38}$ Currently there is a trend to identify anti-Semitism in Carl Schmitt's thinking too. ${ }^{39}$

In the years after his breach with the Association, Schiemann appears to have lived quietly and without much money, owing to the fact that he found it hard to have his journalism published. ${ }^{40}$ What he did write remained critical of Nazism. WhenBaltic Germans were resettled out of Latvia in 1939-40, Schiemann remained to experience Soviet occupation. Later, when the Nazi occupation of the Baltic began, he was put under house arrest. Despite aging and being in poor health, Schiemann nonetheless managed to protect a young Jewish girl from the Holocaust, an action recognised by Yad Vashem which has included his name among "the Righteous among Nations". ${ }^{11}$ He died on 23 June 1944 with Riga still under Nazi occupation, although threatened by advancing Soviet troops.

At the time of his death, Paul Schiemann had recanted his liberal democratic, multicultural beliefs not one iota. He retained a sure moral 
compass the like of which most of us can only envy. It is sad, therefore, that so few people know his name. Although the late John Hiden wrote a fine study of Schiemann's life, nonetheless outside of Latvia and beyond academic circles interested in a few specialist areas such as Baltic German History and the History of European Minorities, his story remains under-exposed. ${ }^{42}$ Perhaps it's time to try to rectify this oversight.

\section{Notes}

1. Mann's broadcasts published as Listen Germany! Twenty Five Radio Messages to the German People over BBC [sic] (New York: A.A. Knopf, 1943).

2. For a discussion of the relationship of Heidegger to Nazism, see Richard Wolin (ed.), The Heidegger Controversy. A Critical Reader (Cambridge, Massachusetts: MIT Press, 1993), also Karl Löwith, Martin Heidegger and European Nihilism (New York: Columbia University Press, 1995). On Carl Schmitt, see Jens Meierheinrich and Oliver Simons (eds.), The Oxford Handbook of Carl Schmitt (New York: Oxford University Press, 2017).

3. Konrad H. Jarausch, The Unfree Professions. German Lawyers, Teachers and Engineers, 1900-1950 (New York: Oxford University Press, 1990); Martyn Housden, Hans Frank: Lebensraum and the Holocaust (Basingstoke: Palgrave, 2003), 47-48.

4. G.M. Gilbert, The Psychology of Dictatorship (New York: Ronald Press, 1950), 136.

5. John Hiden, Defender of Minorities. Paul Schiemann, 1876-1944 (London: Hurst, 2004), 5.

6. Hiden, Defender, 17.

7. Paul Schiemann, "Stadt und Parteien," Rigasche Rundschaunr. ?/ end of January 1920. All Schiemann's essays from Rigasche Rundschau which are cited in this article are reproduced in H. Donath (ed.), Paul Schiemann. Leitartikel, Reden und Aufsätze (Published privately: Frankfurt a.M., 1986). Unless otherwise stated, this essay relies on "Band II 1919-1933, Heft 1: Juli 1919 bis April 1920". For the sake of consistency, referencing follows Donath's identification of newspaper edition numbers.

8. Raymond Pearson, National Minorities in Eastern Europe. 1848-1945 (London: Macmillan, 1983), 177.

9. Paul Schiemann, "Baltische Demokratie”, Rigasche Rundschau, nr. 1 / 1919. In Donath (ed.), Paul Schiemann.

10. Paul Scheimann, "Sozialdemokratie und Gewissensfreiheit. Ein offener Brief an den Stadtverordneten Zelmes," Rigasche Rundschau, nr. 41 / 1919. In Donath, Paul Schiemann.

11. Paul Schiemann, "Chauvinismus," Rigasche Rundschau, nr. 14 / 1919. In Donath (ed.), Paul Schiemann.

12. Paul Schiemann, "Demokratie und Volksstimmung," Rigasche Rundschau, nr. 29 / 1919. In Donath (ed.), Paul Schiemann. 


\section{Housden}

13. Paul Schiemann, "Staatssprache und Landessprache," Rigasche Rundschau, nr. 143 / 1920. In Donath, Paul Schiemann. In this instance see his "Band II 1919-1933, Heft 2: Mai 1920 bis September 1920".

14. Schiemann, "Sozialdemokratie und Gewissensfreiheit."

15. Paul Schiemann, “Die Judenfrage. III," Rigasche Rundschau, nr. 160 / 1922. In Donath, Paul Schiemann, on this occasion "Band II 1919-1933. Heft 5: Januar bis August 1922".

16. For a figure of 40 million, see Ewald Ammende, Gefährdung des europäischen Friedens durch die nationale Unduldsamkeit (Vienna: Friedrich Jasper, undated) 10. For a figure of 20 million, see O.I. Jankowsky, Nationalities and National Minorities (New York: Macmillan, 1945), 111.

17. Ewald Ammende, "Moskaus neue Offensive," Baltische Blätter, 15 and 22 January 1925.

18. For an introduction to the minority system, see Martyn Housden, The League of Nations and the Organisation of Peace (London: Pearson, 2012), 50-55.

19. "Arbeitsprogramm des Vorstandes des Verbandes," undated typescript. 1502-1-61. Russian State Military Archive, Moscow.

20. Ibid.

21. Sitzungsbericht des Kongresses der organisierten nationalen Gruppen in den Staaten Europas im Jahre 1925 zu Genf (Vienna: Wilhelm Braumüller, 1926), 12-13.

22. Ibid, 17-20. Some of Schiemann's key themes are explored more fully in his article "Volksgemeinschaft und Staatsgemeinschaft," Nation und Staat (September 1927).

23. Sitzungsbericht des Kongresses der organisierten nationalen Gruppen in den Staaten Europas. Genf 25.-27. August 1926 (Vienna: Wilhelm Braumüller, 1927), 34-43.

24. For Schiemann on loyalty to the state in which minorities live, see Sitzungsbericht des Kongresses der organisierten nationalen Gruppen in den Staaten Europas. Genf 22.-24. August 1927 (Vienna: Wilhelm Braumüller, 1928), 26.

25. Alfred Rosenberg, The Myth of the Twentieth Century (Torrance, CA: Noontide Press, 1982), 42.

26. Adolf Hitler, Hitler's Secret Book (New York: Grove Press, 1961), 160-90. Also Eberhard Jäckel, "Die Eroberung von Raum in Hitlers Weltanschauung," in W.Wippermann (ed.) Kontroversen um Hitler (Frankfurt aM: Suhrkamp, 1986), 149.

27. The paragraph structure follows that used in the original text. Paul Schiemann, "Nationalsozialismus. II," Rigasche Rundschau, nr. 271 / 1930. In Donath, in this case "Band II 1919-1933. Heft 14: März - Juli 1931".

28. For changes within the German national minorities movement, see the following: John Hiden, Defender, chapter 9; Martyn Housden, On their Own Behalf: Ewald Ammende, Europe's National Minorities and the Campaign for Cultural Autonomy 1920-1936 (Amsterdam: Rodopi, 2014), chapter 11; and Sabine Bamberger-Stemmann, Der EuropäischeNationalitätenkongreß 1925 bis 1938. Nationale Minderheiten zwischen Lobbyistentum und Großmachtinteressen (Marburg: Verlag Herder-Institut, 2000).

29. Housden, On their Own Behalf, 256.

30. Norbert Gürke, "Der Nationalsozialismus, das Grenz- und Auslanddeutschtum und das Nationalitätenrecht," Nation und Staat, October 1932.

31. Ferdinand von Üxküll-Guldenband, "Deutschlands volkspolitisches Programm," 
Nation und Staat, June 1933.

32. Paul Schiemann, "Die neue nationalistische Welle," Nation und Staat, September 1932.

33. Ibid.

34. Ibid.

35. Ibid.

36. For details on funding ties between Berlin and national minorities, see Housden, On their Own Behalf, chapters 12 and 13. Also see Bamberger-Stemmann, Der EuropäischeNationalitätenkongreß.

37. IvarsIjabs, "Strange Baltic Liberalism: Paul Schiemann's Political Thought Revisited," Journal of Baltic Studies, 40 (2009): 495-515.

38. For a critical discussion of Heidegger and the place of anti-Semitism in his thinking, see Journal of Aesthetics and Phenomenology, Issue 2, 2017, special edition, Thinking Contemporary Art with Heidegger. Likewise, see Donatella Di Cesare, Heidegger and the Jews: The Black Notebooks (Cambridge: Polity Press, 2018).

39. Raphael Gross, "The 'True Enemy': Anti-Semitism in Carl Schmitt's Life and Work," in Meierheinrich and Simons (eds.), The Oxford Handbook of Carl Schmitt.

40. For Schiemann's life after 1933, see Hiden, Defender, chapters 10 and 11.

41. Valentina Freimane, "Remembering Paul Schiemann 1876-1944," Journal of Baltic Studies, 31 (2000): 432-37. For link about "Righteous among Nations": http:// db.yadvashem.org/righteous/family.html?language $=$ en\&itemId $=4022625$.

42. For Schiemann's biography, see, Hiden, Defender. For recent efforts inside Latvia to publicise Schiemann's life and ideas, see David Smith, "Why Remember Paul Schiemann?" in David J. Smith (ed.), Latvia. A Work in Progress. 100 Years of Stateand Nation-Building (Stuttgart: Ibidem, 2017). 